\title{
REVIEW
}

\section{Prostate cancer progression after androgen deprivation therapy: mechanisms of castrate resistance and novel therapeutic} approaches

\author{
T Karantanos, PG Corn and TC Thompson
}

Prostate cancer is the second-leading cause of cancer-related mortality in men in Western societies. Androgen receptor (AR) signaling is a critical survival pathway for prostate cancer cells, and androgen-deprivation therapy (ADT) remains the principal treatment for patients with locally advanced and metastatic disease. Although a majority of patients initially respond to ADT, most will eventually develop castrate resistance, defined as disease progression despite serum testosterone levels of $<20 \mathrm{ng} / \mathrm{dl}$. The recent discovery that $A R$ signaling persists during systemic castration via intratumoral production of androgens led to the development of novel anti-androgen therapies including abiraterone acetate and enzalutamide. Although these agents effectively palliate symptoms and prolong life, metastatic castration-resistant prostate cancer remains incurable. An increased understanding of the mechanisms that underlie the pathogenesis of castrate resistance is therefore needed to develop novel therapeutic approaches for this disease. The aim of this review is to summarize the current literature on the biology and treatment of castrateresistant prostate cancer.

Oncogene (2013) 32, 5501-5511; doi:10.1038/onc.2013.206; published online 10 June 2013

Keywords: castrate-resistant prostate cancer; ADT; alternative pathways

\section{INTRODUCTION}

The mainstay of therapy for patients with locally advanced prostate cancer, metastatic prostate cancer and biochemically recurrent disease after failure of localized treatments is androgen-deprivation therapy (ADT) with gonadropin-releasing hormone analogs and anti-androgens. ${ }^{1}$ Gonadropin-releasing hormone analogs like leuprolide cause continuous stimulation of the pituitary gland, leading to 'chemical castration' with suppression of testosterone production from the testes, whereas anti-androgens directly inhibit the androgen receptor (AR).

ADT is known to provide remission of the disease, best evidenced by a decline of prostate-specific antigen (PSA) in about $90 \%$ of patients. ${ }^{2}$ After a mean time of $2-3$ years, however, the disease progresses despite continuous hormonal manipulation. This type of cancer is known as castrate-resistant prostate cancer $(\mathrm{CRPC}){ }^{2}$ Metastatic castration-resistant prostate cancer (mCRPC) is associated with a poor prognosis and mean survival time of only 16-18 months. ${ }^{3}$

Docetaxel and cabazitaxel are the only United States Food and Drug Administration (FDA)-approved chemotherapies for the treatment of mCRPC (Table 1). These tubulin-binding taxanes have been proven to decrease PSA levels and palliate symptoms but survival benefits are modest. ${ }^{4}$ Another agent, sipuleucel-T (Provenge; Dendreon Corp., Seattle, WA, USA) is a cellular immunotherapy that has been shown to increase overall survival time by 4.1 months on average but not progression-free survival time for patients with $\mathrm{mCRPC}$ (Table 1).
The AR is believed to remain active in CRPC, and several new strategies to inhibit AR signaling have recently been developed. Abiraterone acetate (Zytiga; Janssen Biotech, Inc. Horsham, PA, USA) is an FDA-approved inhibitor of androgen biosynthesis, which blocks cytochrome P450-c17 (CYP17), leading to suppression of androgens derived from the adrenal glands, the prostate tumor and the tumor microenvironment (Table 1$)^{8}$ This novel therapy increased survival time by almost 4 months, increased the time to PSA progression, and was relatively well tolerated by patients who had failed chemotherapy. ${ }^{8}$ Moreover, according to a phase III clinical trial, abiraterone acetate led to increased radiographic progression-free survival and overall survival in patients with chemotherapy-naive mCRPC. ${ }^{9}$ MDV3100 (now known as enzalutamide), an AR antagonist that prevents nuclear translocation and chromatin binding, has produced similar results in recent clinical trials (Table 1). ${ }^{10,11}$

Although novel cytotoxic agents, AR-blocking agents and immunotherapies represent effective therapy strategies for $\mathrm{mCRPC}$, important clinical questions remain. First, the absence of any reliable biomarker, apart from serum PSA, for AR-targeted therapies does not allow clinicians to decide which patients will benefit from these treatments or when to alter or terminate treatment. In addition, despite the effective blocking of androgen biosynthesis ${ }^{12}$ and AR signaling, all patients eventually progress. $8,13,14$ Furthermore, the optimal sequencing of these therapies remains unknown.

The general aim of this review is to summarize new evidence about mechanisms of castrate resistance and novel 
Table 1. Therapeutic agents in clinical oncology development for castrate-resistant prostate cancer

\begin{tabular}{|c|c|c|c|c|}
\hline $\begin{array}{l}\text { Therapeutic } \\
\text { agent }\end{array}$ & Mechanism of action & Clinical trial status & Therapeutic efficacy & References \\
\hline Docetaxel & $\begin{array}{l}\text { Stabilization of tubulin, } \\
\text { induction of cell cycle arrest } \\
\text { and inhibition of cell } \\
\text { proliferation }\end{array}$ & FDA approved & $\begin{array}{l}\text { Overall survival benefit and palliation of } \\
\text { cancer-associated symptoms }\end{array}$ & 4 \\
\hline Cabazitaxel & $\begin{array}{l}\text { Stabilization of tubulin, } \\
\text { induction of cell cycle arrest } \\
\text { and inhibition of cell } \\
\text { proliferation }\end{array}$ & $\begin{array}{l}\text { FDA approved for patients after failure of } \\
\text { docetaxel }\end{array}$ & $\begin{array}{l}\text { Overall survival benefit and palliation of } \\
\text { cancer-associated symptoms }\end{array}$ & 4 \\
\hline $\begin{array}{l}\text { Sipuleucel-T } \\
\text { (Provenge) }\end{array}$ & $\begin{array}{l}\text { Enhancement of patients' } \\
\text { autologous antigen-presenting } \\
\text { cells to induce cytotoxic } \\
\text { response against prostate } \\
\text { cancer cells }\end{array}$ & FDA approved & $\begin{array}{l}\text { Increase in overall survival but not } \\
\text { progression-free survival }\end{array}$ & $5-7$ \\
\hline $\begin{array}{l}\text { Abiraterone } \\
\text { acetate }\end{array}$ & $\begin{array}{l}\text { Irreversible inhibition of CYP17 } \\
\text { and subsequent androgen } \\
\text { synthesis }\end{array}$ & $\begin{array}{l}\text { FDA approved in the pre- and post- } \\
\text { docetaxel settings }\end{array}$ & $\begin{array}{l}\text { Increase in overall survival (almost } 4 \\
\text { months), radiographic progression-free } \\
\text { survival, time to PSA progression, and } \\
\text { palliation of cancer-associated symptoms }\end{array}$ & 8,9 \\
\hline \multirow[t]{2}{*}{$\begin{array}{l}\text { MDV3100 } \\
\text { (Enzalutamide) }\end{array}$} & $\begin{array}{l}\text { AR antagonist preventing } \\
\text { nuclear translocation and } \\
\text { binding to chromatin }\end{array}$ & $\begin{array}{l}\text { FDA approved in the post-docetaxel } \\
\text { setting }\end{array}$ & $\begin{array}{l}\text { Increase of overall survival ( } 4.8 \text { months), } \\
\text { radiographic progression-free survival } \\
\text { and time to PSA progression. }\end{array}$ & 10,11 \\
\hline & & $\begin{array}{l}\text { Phase III clinical trial in comparison with } \\
\text { placebo in chemotherapy-naive patients }\end{array}$ & Results pending & \\
\hline BEZ235 & Inhibition of $\mathrm{PI} 3 \mathrm{~K}$ & $\begin{array}{l}\text { Phase I/II clinical trials in combination } \\
\text { with Abiraterone acetate (NCT01717898) }\end{array}$ & Results pending & \\
\hline $\begin{array}{l}\text { RAD001 } \\
\text { (Everolimus) }\end{array}$ & Inhibition of mTOR & $\begin{array}{l}\text { Phase II clinical trial in combination with } \\
\text { bicalutamide (NCT00630344) }\end{array}$ & $\begin{array}{l}\text { Failure to show increase in time to } \\
\text { progression }\end{array}$ & 86 \\
\hline $\begin{array}{l}\text { Dovitinib } \\
\text { (TK1258) }\end{array}$ & Inhibition of FGFR & $\begin{array}{l}\text { Phase II clinical trial in patients after } \\
\text { failure of docetaxel-based chemotherapy } \\
\text { (NCT01741116) }\end{array}$ & Results pending & \\
\hline $\begin{array}{l}\text { Cabozatinib } \\
\text { (XL184) }\end{array}$ & Inhibition of c-MET & $\begin{array}{l}\text { Phase II clinical trial in patients with } \\
\text { mCRPC (NCT01428219) } \\
\text { Phase III clinical trial in comparison with } \\
\text { prednisone in patients previously treated } \\
\text { with docetaxel and abiraterone or } \\
\text { MDV3100 (COMET-1, NCT01605227) } \\
\text { Phase III clinical trial in comparison with } \\
\text { mitoxantrone and prednisone (COMET-2, } \\
\text { NCT01522443) }\end{array}$ & $\begin{array}{l}\text { Reduction of soft tissue lesions, } \\
\text { resolution of bone scans, increase of } \\
\text { progression-free survival } \\
\text { Results pending }\end{array}$ & 140 \\
\hline
\end{tabular}

therapeutic approaches directed at this complex and enigmatic disease state.

\section{THE ROLE OF AR SIGNALING IN CRPC}

The expression of PSA is mediated by androgen response elements. This suggests that the increasing PSA during ADT reflects activation of AR transcriptional activity. ${ }^{15}$ Consistent with this hypothesis, various recent findings have supported the notion that one of the most important mechanisms in CRPC development is the continuous activation of AR in prostate cancer cells. ${ }^{3}$ Several cellular and molecular alterations are related to this postcastration activation of the $A R$, including incomplete blockade of AR-ligand signaling, AR amplifications, AR mutations, aberrant AR co-regulator activities and AR splice-variant expression. ${ }^{16}$

Recent data suggest that despite castration, which decreases serum androgen levels, intratumoral levels of testosterone and dihydrotestosterone in patients with MCRPC are similar to those found in hormone therapy naive. ${ }^{2}$ Evidence suggests that upregulation and stimulation of enzymes involved in androgen biosynthesis such as AKR1C3 occur within the tumor microenvironment ${ }^{17-20}$ while several studies evaluating androgen levels and mRNA levels of relevant enzymes suggest that prostate cancer bone metastases can convert adrenal androgens to testosterone and dihydrotestosterone. ${ }^{19,20}$ Interestingly, according to a recent report by Chang et al., ${ }^{21} \mathrm{mCRPC}$ is dependent on conversion of androstenedione to $5 \alpha$ androstenedione, which is then converted to dihydrotestosterone, bypassing testosterone. Of note, metastatic prostate cancer may amplify the HSD17B3 gene and sustain copy numbers loss of the HSD17B2 gene, leading to decreased conversion of testosterone to the less active androstenedione. ${ }^{22}$ In another recent study, Mitsiades et al. ${ }^{23}$ found significant heterogeneity in the expression of various steroidogenic enzymes in the tumor microenvironment among patients with $\mathrm{mCRPC}$, suggesting that the combination of enzymatic blockage and potent anti-androgens is a reasonable therapeutic approach for patients with mCRPC. Moreover, Efstathiou et al. ${ }^{24}$ recently showed that abiraterone acetate effectively suppresses testosterone concentrations in both blood and the tumor microenvironment to less than picograms per milliliter. Despite this degree of efficacy, patients receiving abiraterone acetate will eventually show evidence of disease progression.

Enzalutamide is a novel AR antagonist that overcomes resistance to conventional anti-androgens by inhibiting nuclear 
localization and chromatin binding of AR. ${ }^{13}$ According to a recent phase I/II study in patients with $\mathrm{MCRPC}$, the use of enzalutamide is safe, elicits PSA and radiographic response, and results in a median time to progression of 47 weeks. ${ }^{10}$ The superiority of enzalutamide over placebo was confirmed in a phase III clinical trial that showed increased overall survival (4.8 months) and improvement in all secondary end points in patients with mCRPC after chemotherapy. ${ }^{11}$ Despite these encouraging results, after a period of remission that is characterized by significant variation in therapeutic response, these tumors eventually progress.

\section{AR amplification}

CRPC is associated with increased expression of AR attributed to gene amplification ${ }^{25}$ and other mechanisms, which include decreased retinoblastoma protein (RB) and increased E2F activity leading to increased AR expression ${ }^{26}$ and anti-androgen-mediated de-repression of AR expression and signaling. ${ }^{27}$ Interestingly, an early study showed that $80 \%$ of the tumors acquiring AR amplification also demonstrated higher levels of AR protein. ${ }^{28}$ Furthermore, studies utilizing fluorescence in situ hybridization have shown that while AR gene amplifications are observed in 20$25 \%$ of CRPC $^{29}$ and in many cancer cell lines derived from these patients, they are very rare in primary tumors. ${ }^{30}$ These gene amplifications, which are heterogeneous among cancerous cells in the same tumor, ${ }^{31}$ are related to sensitization of the AR signaling pathway to lower levels of androgens. On the other hand, AR and AR-regulated genes have been shown to be upregulated in prostate cancer xenografts after castration without any increase in the number of gene copies, ${ }^{32,33}$ suggesting that AR amplification is not the primary mechanism of the paradoxical upregulation of certain AR target genes after castration in these models. ${ }^{32}$

\section{AR mutations}

Multiple early studies evaluating the prevalence of AR gene mutations have demonstrated variable results. ${ }^{34-36}$ Most mutations are located in the ligand-binding domain, providing a mechanistic explanation for the development of resistance to anti-androgen therapy. The results of more recent studies provide support for the hypothesis that the absence of androgens or the presence of anti-androgens acts as selective pressure for emergence of mutations in the AR gene. Consistent with these results, it has been established that $A R$ mutations are rare, but treatment with $A R$ antagonists increase their incidence selecting for mutant ARs. ${ }^{37,38}$ AR mutations documented in mCRPC are related to decreased specificity of AR-ligand interaction, allowing AR activation by alternative steroidal molecules, including estrogens, corticosteroids and progesterone. ${ }^{39,40}$ The $\mathrm{NH} 2$ terminal region, which is known to be critical for the interaction of AR with co-regulators, has also been shown to harbor mutations. $^{41}$ Moreover, mutation analysis identified a 5 -amino-acid core sequence located in the $\mathrm{NH} 2$ terminal region, ${ }^{435}$ WHTLF $^{439}$, which can mediate androgen-independent AR activation. $^{42}$

\section{AR splice variants}

Identification of AR splice variants in cell lines and tumor tissues derived from patients with CRPC provides an additional mechanistic explanation for the development of CRPC. ${ }^{43,44}$ Many of these variants result from insertion of cryptic exons downstream of the coding sequences for the DNA-binding domain or from deletion of exons coding for the ligand-binding domain, leading to the formation of an AR molecule lacking the ligand-binding domain. ${ }^{45,46}$ The regulation of variant $A R$ expression is poorly understood, although suppression of ligand-binding domain by an androgen antagonist is known to cause increased expression of AR variants in prostate cancer cell lines. ${ }^{47}$ Sun et al. ${ }^{46}$ suggested that activation of AR variants leads to upregulation of steroidogenic enzymes, providing prostate cancer cells with higher levels of AR ligands. AR variants are also believed to increase the expression of AR-regulated genes in the absence of any ligand, providing an explanation for the activated AR signaling pathway in CRPC. ${ }^{46,47}$

Hu et al. ${ }^{47}$ recently used LNCaP95 and VCaP prostate cancer cells to show that inhibition of AR by either small interfering RNA or enzalutamide leads to upregulation of the ARV7 ligand, one of the most frequently observed AR variants in clinical specimens. Of note, full-length AR and ARV7 are expressed differently in each cell line. Full-length AR activates pathways related to biosynthesis, metabolism, and secretion, whereas ARV7 increases the expression of cell-cycle genes, including the activator of the M-phase check point UBE2C. ${ }^{47}$ Moreover, when LuCaP35CR xenografts were treated with abiraterone acetate, both fulllength $A R$ and ARV7 were upregulated, but the expression of UBE2C paralleled expression of ARV7. This relationship was also demonstrated in clinical prostate cancer samples following ADT. ${ }^{47}$ Inhibition of AR in LNCaP and CWR22Rv1 cells did not induce activation of $A R$ variants, providing an explanation for why some xenografts respond to AR suppression with tumor growth inhibition. In a recent report by Li et al., ${ }^{48}$ a $48-\mathrm{kb}$ deletion in AR intron 1 was identified in a subset of cells in the heterogeneous CWR-R1 cell line, and was related to the expression of the AR1/2/3/ CE3 splice variant (AR-V7/AR3). Following enzalutamide treatment, the AR-V7/AR3-expressing clone expanded and the presence of this variant contributed to tumor growth during ADT. Of interest is that treatment of AR-V7/AR3-enriched LNCaP cells with high concentrations of dihydrotestosterone caused upregulation of PSA but downregulation of M-phase genes, including UBE2C, CDCA5 and CCNA2. These results implicate expression of AR splice variants in the pathogenesis of CRPC, especially after enzalutamide treatment. ${ }^{48}$ Finally, genomic deletion of exons 5-7 has been related to increased expression of ARV12 in prostate cancer cell lines ${ }^{44}$ while AR-antagonists targeting the N-terminal domain are believed to be effective against these variants. ${ }^{49}$

\section{Post-translational modifications of AR}

Other possible mechanisms related to persistent AR transcriptional activity during ADT are post-translational alterations of AR, especially phosphorylation. Guo et al. ${ }^{50}$ suggested that Src-induced phosphorylation of ARY534 can lead to both AR sensitization to low levels of androgens and androgenindependent activation of AR. Moreover, it is believed that Etk, a non-receptor tyrosine kinase and downstream effector of Src and phosphatidylinositol 3 kinase (PI3K), is upregulated during ADT and phosphorylates AR at Y534 and Y551/552, stabilizing it and promoting its activity under androgen-depleted conditions. ${ }^{51}$ Finally, Tyr284 phosphorylated and activated ACK1 has been related to increased Tyr267 phosphorylation of AR, disease progression and decreased survival of PCa patients. ${ }^{52}$

\section{AR co-regulators and collaborating factors}

Another critical mechanism implicated in the development of CRPC is the interaction between AR and co-regulators. Wang et al. ${ }^{53}$ showed in a castrate-resistant LNCaP derivative that AR directly regulates $M$ phase genes including $C D C 20, C D K 1$ and UBE2C, inactivating the M-phase check point and promoting tumor growth in xenografts. Chromatin immunoprecipitation analysis showed enhanced activities of the AR co-stimulator MED1 and of the FoxA1 and GATA2 AR collaborating factors in castrationresistant cells, whereas silencing of these factors decreased UBE2C mRNA levels. ${ }^{53}$ Results from this study indicate that the distinctive pattern of AR transcriptional activity in castrateresistant cells is determined to a large extent by coactivator stimulation and accompanying chromatin modifications. It is interesting that interleukin 6-mediated nuclear receptor 
coactivator 1 (NCoA1, or SRC-1) phosphorylation promotes ARdependent transcription in a ligand-independent manner, whereas mitogen-activated protein kinase (MAPK)-mediated phosphorylation of this coactivator may increase its affinity for AR, contributing to disease recurrence and CRPC. ${ }^{54}$

It is also known that bicalutamide therapy reduces recruitment of the nuclear receptor co-repressor (NCoR) in cells with increased AR protein. ${ }^{32}$ According to recent reports, NCoA2 (SRC-2) expression is positively associated with high tumor cell proliferation and early disease relapse. ${ }^{55}$ Downregulation of $\mathrm{NCOA} 2$, which is amplified in a subset of PCa reduces AR target gene expression and inhibits proliferation of AR-dependent and -independent prostate cancer cells, whereas it is believed that in AR-positive cancer cells, high levels of androgens repress $\mathrm{NCOA} 2$ expression. ${ }^{56}$ Finally, NCoA3 (SRC-3), which is positively associated with tumor recurrence and $\mathrm{PI} 3 \mathrm{~K} / \mathrm{Akt}$ activation, is known to be critical in the development of poorly differentiated prostate cancer. $^{57}$

\section{AR transcriptional activity}

During the development of CRPC, AR transcriptional activity is modified and aberrant regulation of numerous genes that promote cell survival and proliferation occurs. Available data indicate that AR-stimulated genes are initially repressed but subsequently rebound during ADT. For example, Holzbeierlein et $a .^{58}$ reported a gene-expression analysis of prostate tumors during hormonal therapy showing that multiple AR target genes were upregulated during ADT and were associated with clinical resistance to therapy. Moreover, Sharma et al. ${ }^{26}$ suggested that retinoblastoma protein loss and subsequent E2F transcriptional factor stimulation can lead to deregulation of AR and androgenindependent activation of multiple AR-stimulated genes. Recent reports added support to the concept that multiple alternative oncogenic pathways can contribute to generation of AR signaling that is hypersensitive to low levels of androgens. ${ }^{59}$

During AR signaling, AR can act as either a transcriptional enhancer or repressor for downstream target genes depending on androgen levels. For example, Cai et al. ${ }^{27}$ found that with increasing androgen levels, AR directly represses transcription of the AR gene in androgen-dependent VCaP cells through the ARBS2 enhancer located within intron 2 of the AR gene. In contrast, with low androgen levels following androgen deprivation, transcription of the AR gene increases. Additional AR target genes involved in androgen biosynthesis, DNA synthesis and repair, cell cycle and proliferation are similarly repressed with high androgen levels and become de-repressed with low androgen levels. Consistent with these activities, expression of androgen-repressed genes is increased in castrate-resistant VCaPderived VCS2 cells and VCaP xenografts, and in human CRPC samples. These data suggest a model of castrate resistance whereby androgen levels are adequate to enhance expression of positively regulated $A R$ target genes related to cellular metabolism, but are insufficient to recruit AR and lysine-specific demethylase 1 to suppressor elements on genes that are negatively regulated by $A R$, and are related to DNA replication and cellular proliferation. ${ }^{27}$ Thus, a combination of enhanced and de-repressed AR target genes ultimately contributes to castrateresistant progression (Figure 1).

\section{ALTERNATIVE GROWTH AND SURVIVAL PATHWAYS IN CRPC}

During the transition from androgen dependence to castrate resistance, cancer cells become driven by alternative growth signaling pathways. Many of these pathways can participate in normal cellular processes, but can also become oncogenic in the early adaptive period after ADT has begun. ${ }^{60}$ An increased understanding of the molecular interactions between androgen signaling and these alternative growth and survival pathways should lead to the identification of novel therapeutic targets.

\section{C-myc overexpression}

The proto-oncogene c-myc is a known regulator of cell growth and has a critical role in prostate cancer development and progression. Gurel et al. ${ }^{61}$ showed that c-myc is frequently overexpressed in prostate intraepithelial lesions (PINs) with an incremental increase from normal tissues to low-grade PIN to high-grade PIN. Various mouse models have shown that c-myc overexpression in prostate luminal cells can lead to hyperplasia and PIN lesions but not invasive carcinoma. ${ }^{62-64}$ Alternatively, genetically engineered mice that express higher levels of c-myc from the ARR2PB prostate-specific promoter develop PIN that progresses to prostate cancer with variable frequencies. ${ }^{65,66}$ Interestingly, specific amplifications of the c-myc gene have been confirmed in up to $72 \%$ of CRPC $^{67}$ and ADT has been suggested to increase the incidence of these amplifications. ${ }^{68}$ Finally, Bernard et al. ${ }^{69}$ demonstrated that while AR inhibition causes downregulation of c-myc in prostate cancer cells, prostate cancer cells that overexpress c-myc continue to grow under ADT. Together, these data support a role for c-myc activation in the development of prostate cancer and as a potential mechanism for CRPC development.

The PI3K/Akt/mammalian target of rapamycin (mTOR) pathway The PI3K pathway is one of the most critical in human cancer. ${ }^{70}$ Various growth factors, including insulin-like growth factor (IGF) and fibroblast growth factor (FGF), regulate this pathway, leading to activation of PI3K and the formation of PIP3. PIP3 activates AKT via phosphorylation and phosphorylated Akt (pAkt) activates multiple molecules involved in cell survival and proliferation, including MDM2, c-myc, GSK3 $\beta$, nuclear factor- $\kappa B$ and $m T O R$. Phosphatase and tensin homolog deleted on chromosome 10 (PTEN) is a lipid phosphatase that functions as the main inhibitor of PI3K/Akt signaling. Genetic alterations of the PI3K signaling pathway occur in $42 \%$ and $100 \%$ of primary and metastatic prostate cancers, respectively, suggesting this pathway is crucial in the development of CRPC. ${ }^{60}$

In an important study using the $\mathrm{PbCre}$; Pten ${ }^{\text {loxp/loxp }}$ mouse model characterized by prostate-specific inactivation of PTEN Wang et al., ${ }^{71}$ showed that $100 \%$ of mice developed invasive adenocarcinoma between 9 and 29 weeks, 5 of 11 had lymph node metastasis between 12 and 29 weeks, and 3 of 11 mice developed lung metastases. Following castration, there was a time-dependent phenotype characterized by an immediate initial increase in prostate cancer cell apoptosis (3 to 6 days postcastration) that was gradually replaced over time with the outgrowth of Pten null castrate-resistant proliferative clones. The results of more recent studies using Pten-knockout mice are generally consistent with the initial reports, yet time to progression to PCa may be variable. In this regard, transgenic mouse models with combined PTEN and p53 knockout lead to rapid PCa development with higher incidence. ${ }^{72-74}$

Results from PI3K, Akt and mTOR inhibitors in clinical trials and xenograft studies ${ }^{75-77}$ suggested a potential interaction between $\mathrm{AR}$ and PI3K/Akt signaling pathways. Two recent publications reported negative feedback regulation between AR and PI3K/Akt pathways. First, Carver et al. ${ }^{78}$ initially observed that mice with prostate Pten deletion (Pten ${ }^{\text {loxp/loxp }}$ ) had lower AR levels than their wild-type littermates, whereas treatment with BEZ235, a dual PI3K and mTOR inhibitor, and RAD001, an mTOR inhibitor, rescued AR protein levels. Similar results were achieved in LNCaP cells, demonstrating that $\mathrm{PI} 3 \mathrm{~K}$ pathway inhibition can upregulate $A R$ and activate AR target gene expression. ${ }^{78}$ Subsequent experiments in LNCaP cells and Pten ${ }^{\text {loxp/loxp }}$ mice showed that 

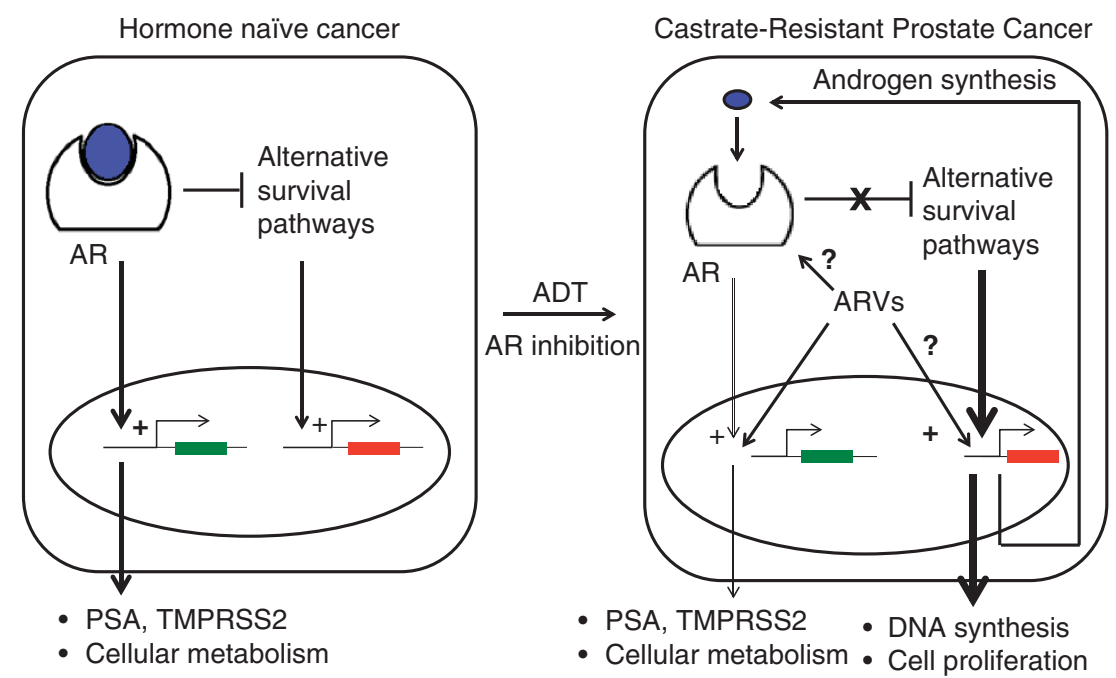

Figure 1. Androgen deprivation therapy initiates alterations in gene-expression profiles in prostate cancer cells. AR induces the expression of PSA, transmembrane protease serine 2 (TMPRSS2) and multiple genes related to cellular metabolism. AR signaling also inhibits the activation of alternative survival pathways, that is, PI3K/Akt. ADT results in de-repression of alternative survival pathways inducing the expression of genes related to DNA synthesis and cell proliferation and in recalibration of prostate cancer tissue androgen levels leading to partial restoration of AR transcriptional activity. ADT may also lead to expansion of prostate cancer cells expressing AR variants (ARVs), which may contribute to altered gene expression.

this PI3K-AR interaction is mediated in part by upregulation of HER3 after inhibition of PI3K. ${ }^{78}$

Second, Mulholland et al. ${ }^{79}$ used the PbCre;Pten loxp/loxp model to demonstrate that Pten loss suppresses AR transcriptional activity and generates a gene-expression profile resembling that of the castration phenotype. A mechanism for this crosstalk involved negative regulation of EGR1, c-JUN and EZH2 by PTEN. Interestingly, according to a study by Lin et al., ${ }^{80} \mathrm{Akt}$ phosphorylates AR leading to increased AR ubiquitinylation and degradation suggesting an alternative mechanism for the negative crosstalk between $A R$ and Akt. These reports demonstrate that the PI3K/Akt pathway can inhibit AR transcriptional activity. It should be mentioned that in an earlier study Wang et al. ${ }^{81}$ found that rapamycin stimulated AR transcriptional activity while the combination of rapamycin and bicalutamide increased apoptosis in prostate cancer cells. The authors attributed this effect to negative crosstalk between Aktindependent mTORC1 signaling and AR in prostate cancer cells. Finally, other studies indicate that specific experimental conditions and/or genetic manipulations may lead to results that are not consistent with negative crosstalk between AR and Akt. $^{82,83}$

Additional experiments showed that after 7 days of enzalutamide treatment of Pten loxp/loxp mice, despite decreased AR transcriptional activity the tumors had not significantly regressed and were histologically similar to those before treatment, although the treatment was much more effective in transgenic mice with inducible c-myc. ${ }^{78}$ Further studies revealed increased Akt phosphorylation at Ser473 in the Pten ${ }^{\text {loxp/loxp }}$ mice and in LNCaP and LAPC4 AR-positive cells after castration and enzalutamide treatment, respectively. The same treatment did not increase pAkt in PC-3 cells, which are AR negative. ${ }^{78}$

Similarly, Mulholland et al. ${ }^{79}$ used the PbCre;Pten ${ }^{\text {loxp/loxp }}$ model to show that castrate-resistant cancer developed in the regions of the prostate with combined Pten and AR loss. In contrast, AR-positive regions contained lower levels of pAkt with less cell proliferation after castration. These observations led to the conclusion that active AR transcriptional activity can inhibit phosphorylation of Akt to activate a potent oncogenic pathway. Both groups of investigators attributed this interaction to the upregulation of FKBP5 and PHLPP by AR. ${ }^{78,79}$ It is known that
FKBP5 functions as a scaffolding protein for pAkt and PHLPP, promoting pAkt dephosphorylation by PHLPP. ${ }^{84}$

Cross talk between the AR and PI3K/Akt pathways supports the rationale for combining $A R$ and $\mathrm{PI} / \mathrm{Akt}$ inhibitors in CRPC. Although BEZ235 and enzalutamide modestly inhibit LNCaP cell proliferation as single agents, the combination significantly decreased cell numbers via apoptosis in vitro. In LNCaP xenografts, the combination produced a greater reduction of tumor volume compared with vehicle-only or single therapy (that is, BEZ235 or castration only). ${ }^{78}$ Mulholland et al. ${ }^{79}$ compared treatment of Pten ${ }^{\text {loxp/loxp }}$ mice and Pten ${ }^{\text {loxp/loxp }}$ mice carrying AR deletion (Pten ${ }^{\operatorname{loxp} / \operatorname{loxp}} A R^{L} / Y$ ) with rapamycin only, castration only or the combination. They found significantly enhanced tumor regression in the combination-therapy group relative to that in the two single therapy groups in both models. Despite these encouraging results, recent data indicate complex adaptive resistance pathways to $\mathrm{PI} 3 \mathrm{~K} / \mathrm{mTOR}$ inhibition in vivo, and clinical data are lacking. ${ }^{85}$ Finally, it should be noted that the efficacy of BEZ235 and RAD001 for MCRPC in combination with bicalutamide are currently being evaluated in phase I and II clinical trials $^{86}$ (Table 1).

Other growth and survival pathways contributing to CRPC

The RAS/MAPK pathway has also been implicated in prostate cancer development, progression and metastasis. RAS signaling is known to decrease the androgen dependence of LNCaP cells $s^{87}$ and to promote metastasis in DU145 cells, and tissue specimens from patients with MCRPC display higher levels of PMAPK, a downstream target of RAS signaling. ${ }^{88}$ According to a recent report from Mulholland et al., ${ }^{89}$ the RAS/MAPK pathway was activated in $43 \%$ of primary prostate cancer samples and $90 \%$ of metastatic samples. Phospho-MAPK levels were more prominent in tissues derived from patients who had received ADT and were mainly observed in the basal cell compartment. Moreover, although conditionally activated $\mathrm{K}$-ras in the prostatic epithelium of transgenic mice $\left(\mathrm{K}-\mathrm{ras}^{\mathrm{L} / \mathrm{W}}\right)$ is not sufficient to promote prostate cancer development, when $\mathrm{K}$-ras ${ }^{\mathrm{L} / \mathrm{W}}$ mice were crossed with PbCre;Pten ${ }^{\text {loxp/loxp }}$ mice, simultaneous deletion of Pten and activation of RAS led to the 
development of poorly differentiated carcinoma within 10 weeks. $^{89}$ In contrast with the PbCre;Pten ${ }^{\text {loxp/loxp mice, }}$

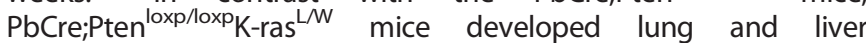
metastases with $100 \%$ penetrance but not bone metastasis, although their expression of AR and AR-targeted genes was much lower. Histologic and gene-expression analysis of cancer tissues showed that expression of mesenchymal markers, including $\mathrm{N}$-cadherin, and cell-cycle genes, including UBE2C, was greater than in $\mathrm{PbCre}$;Pten ${ }^{\text {loxp/loxp }}$ mice, suggesting that RAS pathway activation promotes the de-differentiation of prostate cancer cells.

Transforming growth factor- $\beta$ (TGF- $\beta$ ) is a secreted cytokine that is implicated in various cellular processes, including cell proliferation and cancer progression. ${ }^{90,91}$ Several studies have suggested that in normal epithelial cells and early-stage cancers, TGF- $\beta$ signaling may be growth suppressive. ${ }^{90,92}$ In advanced prostate cancer, however, TGF- $\beta 1$ levels are increased, suggesting a growth promoting role. ${ }^{93-95}$ It has also been shown that the expression of an isoform of this cytokine, TGF- $\beta 3$, is increased in prostate cancer and that TGF- $\beta 3$ signaling is upregulated in CRPC. ${ }^{96}$ Androgens regulate TGF- $\beta 1$ gene transcription through positive and negative androgen response elements in the TGF- $\beta 1$ promoter. ${ }^{97,98}$ However, AR-mediated TGF- $\beta 1$ expression in the context of CRPC is not well understood. Recent data support the idea that TGF- $\beta$ cytokines can activate the PI3K pathway, although the role of SMAD molecules in this interaction is not clear. ${ }^{99,100}$ One report suggested that the TGF- $\beta$ and PI3K pathways contribute to epithelial to mesenchymal transition (EMT), which is believed to be important in CRPC pathogenesis. ${ }^{101}$ Among the most important intracellular mediators of TGF- $\beta$ signaling are the SMAD isoforms. Ding et al. ${ }^{102}$ used a transgenic mouse model to evaluate the role of SMAD4 in prostate cancer progression and metastatic potential. In prostate intraepithelial neoplastic lesions in PTEN ${ }^{\text {loxp/loxp }}$ mice, TGF- $\beta$ signaling is upregulated and these lesions are characterized by increased SMAD4 expression. Interestingly, SMAD4 was previously reported to be downregulated in human prostate cancer metastasis, and epigenetic silencing of the SMAD4 promoter was associated with advanced disease. ${ }^{103}$ Ding et al. ${ }^{102}$ found that Pten ${ }^{-/-}$Smad4 $4^{-/-}$ mice developed earlier and more aggressive invasive adenocarcinoma than Pten ${ }^{-1-}$ mice, whereas Smad4 ${ }^{-1-}$ mice did not develop prostate cancer. Gene-expression analysis of these models showed that cyclin D1 and SPP1 were upregulated in Pten $^{-1-}$ Smad4 ${ }^{-1-}$ tumors, leading to an increased proliferation index.

The Wnt/ $\beta$-catenin pathway is dysregulated in several types of cancer, including colorectal, liver and prostate cancer. ${ }^{104,105}$ In one study, abnormal $\beta$-catenin expression was observed in $23 \%$ of tumor samples derived from radical prostatectomies and in $38 \%$ of CRPCs and was found to be related to high Gleason scores. ${ }^{106}$ $\beta$-Catenin activates T-Cell factor/lymphoid enhancer factor-1 (TCF/ LEF-1) transcriptional activity and upregulates genes such as MYC, MMP7 and vascular endothelial growth factor. On the other hand, $\beta$-catenin is an important component of cadherin cell adhesion complexes, which have a critical role in the development of EMT and CRPC. ${ }^{107}$ A functional relationship between Wnt/ $\beta$-catenin signaling and EMT has also been suggested. ${ }^{108}$ Among the Wnt/ $\beta$ catenin target genes are the transcriptional factors Twist-related proteins 1 and 2 and the zinc-finger protein SNAI2, which downregulate E-cadherin, potentially contributing to EMT. ${ }^{109}$

Despite extensive research, there are conflicting results regarding the crosstalk between $A R$ and $W n t / \beta$-catenin signaling. Some studies suggest that AR activation leads to increased $\beta$-catenin nuclear translocation and transcriptional activity. ${ }^{10,111}$ Other studies indicate that stimulation of Wnt/ $\beta$-catenin signaling leads to increased AR expression via TCF/LEF-1-binding sites on the AR promoter ${ }^{112}$ and also upregulation of AR target genes. ${ }^{102,103}$ However, AR has also been shown to compete with TCF/LEF-1 for $\beta$-catenin binding and therefore inhibit $\beta$-catenin/
TCF-dependent signaling. ${ }^{13,114}$ Consistent with the latter findings, Chesire and Isaacs, ${ }^{115}$ in an early study involving experiments in prostate and non-prostate cancer cells, showed that stimulation of $A R$ by androgens can lead to AR-mediated transcriptional suppression of $\beta$-catenin/TCF transcriptional activity, whereas activation of TCF may inhibit the expression of AR-regulated genes. Administration of anti-androgens alleviated this ARmediated suppression of TCF transcriptional activity. Finally, in a recent study, nuclear localization of $\beta$-catenin was found in 10 of 27 human tissue specimens derived from bone metastases of mCRPC. This localization was inversely associated with AR expression, suggesting that reduced AR expression enables $\beta$-catenin signaling. $^{116}$

The IGF system has been implicated in growth regulation, apoptosis resistance and invasion in a number of human malignancies, ${ }^{117-119}$ but its role in the development of CRPC remains controversial. Studies in prostate cancer cells have shown that IGF-1 may increase cancer cell proliferation and glucose consumption, whereas inhibition of the IGF-1 receptor (IGF-1R) suppresses prostate cancer cell invasiveness. ${ }^{120,121}$ Xenograft studies demonstrated that increased IGF-1R and IGF-1 can lead to androgen-independent tumor growth. ${ }^{122}$ Pandini et al. ${ }^{123}$ found that $A R$ stimulation leads to increased expression and phosphorylation of IGF-IR in AR-positive cancer cells, enhancing their proliferation and invasiveness. Importantly, this increased AR activity was only partially blocked by anti-androgens such as bicalutamide.

IGF is known to mediate the activity of insulin and IGF-1 and -2 in normal cells, thereby mediating increased glucose uptake and glycolysis resulting in ATP and $\mathrm{CO}_{2}$ formation via oxidative phosphorylation. In contrast with normal cells, most cancer cells rely on aerobic glycolysis-the Warburg effect. Aerobic glycolysis increases the uptake of nutrients that are critical for cell proliferation and tumor growth, including nucleotides, amino acids and lipids. At the same time, aerobic glycolysis via the pentose phosphate pathway alleviates cellular oxidative stress, providing cancer cells with a survival advantage. ${ }^{124}$ According to another recent study, the administration of aerobic glycolysis inhibitors such as 3-bromopyruvate can overcome resistance to trastuzumab in breast cancer ${ }^{125}$ and induce cell death in myeloma cells that overexpress hexokinase II. ${ }^{126}$ Several studies substantiate the idea that prostate cancer cells activate glycolysis through $\mathrm{AR}$ and $\mathrm{PI} 3 \mathrm{~K} / \mathrm{Akt}$. In particular, Moon et al. ${ }^{127}$ showed that androgen administration activates glycolysis and lipogenesis in LNCaP cells through Protein kinase A (PKA)-mediated phosphorylation of CREB, which leads to upregulation of hexokinase II. In parallel, liganded AR directly stimulates the expression of PFKFB2, a known isoform of phosphofructokinase 2 (PFK2), and PI3K/Akt signaling is implicated in the phosphorylation of PFKFB2, promoting its kinase function. On the other hand, recent data have shown that AR stimulates AMPK, ${ }^{128}$ which is a known negative regulator of Warburg effect. ${ }^{129}$ Interestingly, AR-negative cells such as PC-3 cells exhibit lower PFK activity, higher LDH activity and consume less oxygen than LNCaP (AR-positive) cells. ${ }^{130}$ Ros et al. ${ }^{131}$ demonstrated that LNCaP, DU145 and PC-3 prostate cancer cells are more dependent on glucose than non-malignant RWPE1 cells. Furthermore, inhibition of PFKFB4, another isoform of PFK2 that functions as the phosphatase of fructose 2,6-biphosphate and promotes the pentose phosphate pathway, led to decreased tumor growth in PC-3 xenografts. By inducing the pentose phosphate pathway, this enzyme provides cells with sufficient nicotinamide adenine dinucleotide phosphate for biomass synthesis and for alleviation of oxidative stress. The implication is that aerobic glycolysis, driven by multiple oncogenic pathways, contributes to prostate cancer progression and in the context of CRPC, may reveal potential markers of disease progression and therapeutic targets. 
The FGF pathway is believed to have a critical role not only during prostate organogenesis but also during prostate cancer development. FGF is known to be secreted by both stromal and cancer cells in the tumor microenvironment, acting by paracrine and autocrine mechanisms, respectively. ${ }^{132}$ Consistent with these data, FGF receptor 1 is not expressed in benign prostate epithelium, whereas it is upregulated in $40 \%$ of poorly differentiated adenocarcinomas. ${ }^{133}$ By using a lentiviral vector to alter stromal FGF expression, Memarzadeh et al. ${ }^{134}$ showed that increased stromal FGF can lead to the enhanced epithelial proliferation associated with AR upregulation. Moreover, when stroma-overexpressing FGF and epithelium-expressing activated Akt were combined, tumor growth was more prominent. Acevedo et al. ${ }^{135}$ demonstrated the development of a spectrum of prostate malignancies, including adenocarcinoma, which were positive for nuclear AR and negative for synaptophysin, with lymph node and liver metastasis in mice with conditional overexpression of FGF receptor 1 in the prostate epithelium. There was a high incidence of sarcomatoid carcinoma with relatively diffuse expression of E-cadherin, which is a characteristic of EMT. A clinical trial with Dovitinib (TKI258), a multi-tyrosine kinase inhibitor with highspecific activity against FGF/FGFR, is currently underway in patients with mCRPC (ClinicalTrials.gov Identifier: NCT01741116) (Table 1).

Hepatocyte growth factor and its receptor, c-Met, have been implicated in the regulation of cell growth, cell motility, morphogenesis and angiogenesis by autocrine and/or paracrine mechanisms. ${ }^{136,137}$ c-Met is highly expressed in AR-negative prostate cancer cell lines such as PC-3 and DU145 and in basal and intermediate cells in the prostate epithelium but only minimally expressed in AR-positive prostate cancer cells, including LNCaP and CWR22, and in luminal cells in the prostate epithelium. ${ }^{138}$ Of note, increased c-Met expression has been found in prostate cancer tissues with a greater incidence of staining in metastatic tumor samples. ${ }^{138}$ Finally, Verras et al. ${ }^{139}$ showed that AR downregulates c-Met expression by interfering with Sp1, a known transcriptional factor that stimulates c-Met expression. These data support the idea that c-Met signaling is negatively regulated by $A R$ and is potentially de-repressed during the development of castrate resistance. In a recently reported study, Cabozantinib (XL184), a multi-tyrosine kinase inhibitor with highspecific activity against c-Met, produced significant responses in patients with MCRPC characterized by improvements in bone scan, lymphadenopathy, and bone pain ${ }^{140}$ (Table 1 ).

Recent data substantiate the concept of negative crosstalk between AR- and EMT-promoting pathways and that overexpression of self-renewal pathways can be sufficient for tumor progression during ADT. Sun et al. ${ }^{141}$ recently reported that castration can induce EMT in normal mouse prostate, characterized by increased expression of $\mathrm{N}$-cadherin and vimentin and by low expression of E-cadherin and the acquisition of stem cell characteristics. They confirmed these results in LucaP35 xenografts, which showed increased TGF- $\beta$, IGF1, FGFR2 and platelet-derived growth factor signaling after ADT. The authors also found negative crosstalk between AR and Zeb1, which may be related to EMT. Zhu et al. ${ }^{142}$ found that long-term ADT can promote EMT and metastasis through downregulation of $A R$ expression, suggesting that intermittent ADT is a promising option for patients with late disease. Finally, Jeter et al. ${ }^{143}$ showed that LNCaP cells and xenografts overexpressing NANOG, a known self-renewal and pluripotency gene, are resistant to ADT and characterized by c-myc and Ki-67 upregulation and AR and PSA downregulation, suggesting that NANOG can mediate castrate-resistant progression.

Caveolin-1 (Cav-1) is a major structural component of caveolae that is known to interact with critical components of multiple oncogenic pathways, including receptor tyrosine kinases, serine/ threonine kinases, phospholipases, G-coupled protein receptors and Src family kinases. These proteins are located in caveolar membranes, where they interact with Cav-1 through the Cav-1 scaffolding domain. ${ }^{144,145}$ Elevated expression of Cav-1 is associated with multiple human malignancies, including prostate cancer. ${ }^{146,147}$ Serum Cav-1 levels are higher in men with prostate cancer than in those with benign prostate hyperplasia, ${ }^{148}$ and high serum levels have been associated with elevated risk of cancer recurrence after radical prostatectomy. ${ }^{149}$ Moreover, Cav-1 levels were found to be elevated in metastatic mouse and human prostate cancer, ${ }^{150}$ and this molecule was found to be a downstream effector of testosterone-mediated prostate cancer cell survival and clonal growth. ${ }^{151}$ On the other hand, Cav-1 is known to be highly expressed and secreted by AR-negative cells, and increased levels of Cav-1 expression have been observed after ADT. ${ }^{152}$ Further, downregulation of Cav-1 in cell and animal models converted androgen-insensitive metastatic mouse prostate cancer cells to an androgen-sensitive phenotype. ${ }^{153}$ Finally, recombinant Cav-1 is taken up by prostate cancer cells and endothelial cells in vitro and increases angiogenic activities, suggesting a significant role of Cav-1 not only in the tumor cell but also in the tumor microenvironment. ${ }^{154}$ These data suggest that Cav-1 expression provides a significant survival benefit for prostate cancer cells, especially on ADT.

Mechanistic studies show that Cav-1 induces the PI3K/Akt pathway by inhibiting the phosphatases PP1 and PP2, leading to increased phosphorylation and activity of PDK1, Akt and Erk1/2. ${ }^{155}$

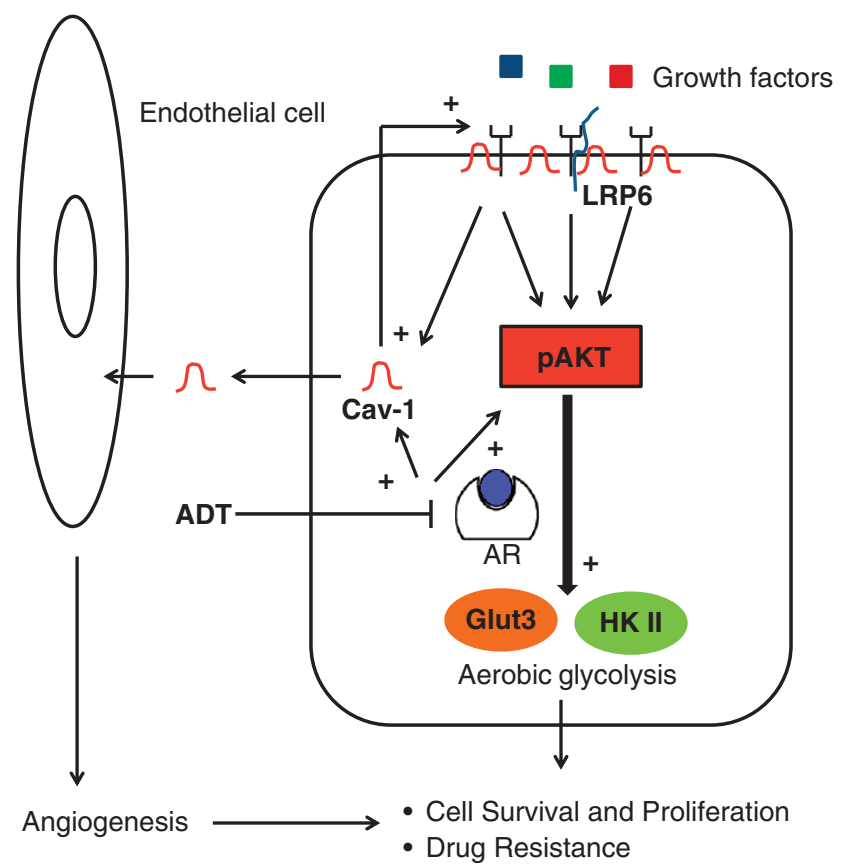

Figure 2. Stimulation of aerobic glycolysis in the development of CRPC. Cav-1 interacts with growth factor receptors and low density lipoprotein receptor-related protein 6 (LRP6). These activities stimulate $\mathrm{PI} 3 \mathrm{~K} / \mathrm{Akt}$ signaling, leading to increased phosphorylation of Akt (pAKT) and increased expression of glycolytic enzymes, that is, glucose transporter 3 (Glut3) and hexokinase II (HK II), promoting aerobic glycolysis. Induction of aerobic glycolyis may contribute to prostate cancer cell survival, proliferation and drug resistance. Cav-1 is secreted by prostate cancer cells and establishes a positive autocrine and paracrine loop within the tumor microenvironment. Secreted, soluble Cav-1 is taken up by prostate cancer cells and can interact with specific growth factor receptors. Cav-1 is also taken up by endothelial cells, and can stimulate angiogenesis, further supporting tumor growth. ADT leads to de-repression of alternative survival pathways, that is, PI3K/Akt and increases Cav-1 expression. These activities may lead to metabolic reprogramming, and potentially contribute to prostate cancer progression. 
As PI3K/Akt is a critical survival pathway for prostate cancer cells, especially during ADT, this explains the significance of Cav-1 expression in AR-negative cells. In a subsequent study, FGF, vascular endothelial growth factor and TGF- $\beta 1$ downstream pathways induced the secretion of Cav-1 in AR-negative cells. Cav-1 upregulates multiple oncogenic pathways through PI3K/Akt and mRNA stabilization, suggesting the presence of a positive feedback loop between Cav-1 and these oncogenic pathways. ${ }^{156}$ In accord with these findings, Tahir et al. ${ }^{157}$ showed that sunitinib and dasatinib treatment of PC-3 and DU145 cells and xenografts decreased Cav-1 expression in cells and serum Cav-1 levels, respectively, in mice and serum Cav- 1 levels were positively associated with tumor growth. Finally, the co-administration of anti-Cav-1 antibody with sunitinib and dasatinib led to greater tumor regression than did either treatment alone, further supporting the concept that Cav-1 mediates activation of multiple oncogenic pathways in the prostate cancer cell. Recently, Tahir et al. ${ }^{158}$ demonstrated an interaction between Cav-1 and LRP6 in the cellular membrane, which leads to the activation of IGF-1R/IR and results in stimulation of Akt-mTORC1mediated activation of aerobic glycolysis that includes upregulation of HK2 and GLUT3. These data, combined with recent results that show a contribution of aerobic glycolysis to prostate cancer progression, suggest a possible role of Cav-1 as an inducer of multiple oncogenic pathways, with aerobic glycolysis being the end result (Figure 2).

\section{CONCLUSION}

Metastatic prostate cancer remains an incurable disease and there are few reliable biomarkers to monitor disease progression or guide therapeutic decisions. The evolution of CRPC involves both androgen-stimulated and -repressed genes related to numerous alternative growth and survival pathways activated during the development of this disease state. Interactions between AR signaling and alternative survival pathways are cell-type and context-dependent and are currently under extensive investigation. Specific oncogenic pathways, for example, PI3K/Akt, are activated in prostate cancer cells and ADT can provide selective pressure in favor of their expression, potentially promoting castrate-resistant growth. Extrapolation of this complex information will hopefully lead to the identification of new predictive and surveillance biomarkers, and novel and combined therapies targeting critical pathways which provide a survival advantage to prostate cancer cells and promote CRPC.

\section{CONFLICT OF INTEREST}

The authors declare no conflict of interest.

\section{ACKNOWLEDGEMENTS}

This research is supported in part by the National Institutes of Health through MD Anderson's Cancer Center Support Grant, 5 P30 CA016672. We thank Karen F Phillips, ELS, for her expert editorial assistance.

\section{REFERENCES}

1 Huggins C. Prostatic cancer treated by orchiectomy; the five year results. J Am Med Assoc 1946; 131: 576-581.

2 Harris WP, Mostaghel EA, Nelson PS, Montgomery B. Androgen deprivation therapy: progress in understanding mechanisms of resistance and optimizing androgen depletion. Nat Clin Pract Urol 2009; 6: 76-85.

3 Marques RB, Dits NF, Erkens-Schulze S, van Weerden WM, Jenster G. Bypass mechanisms of the androgen receptor pathway in therapy-resistant prostate cancer cell models. PLoS One 2010; 5: e13500.

4 Dayyani F, Gallick GE, Logothetis CJ, Corn PG. Novel therapies for metastatic castrate-resistant prostate cancer. J Natl Cancer Inst 2011; 103: 1665-1675.
5 Small EJ, Schellhammer PF, Higano CS, Redfern $\mathrm{CH}$, Nemunaitis JJ, Valone GH et al. Placebo-controlled phase III trial of immunologic therapy with sipuleucel-T (APC8015) in patients with metastatic, asymptomatic hormone refractory prostate cancer. J Clin Oncol 2006; 24: 3089-3094.

6 Higano CS, Schellhammer PF, Small EJ, Burch PA, Nemunaitis J, Yuh L et al. Integrated data from 2 randomized, double-blind, placebo-controlled, phase 3 trials of active cellular immunotherapy with sipuleucel-T in advanced prostate cancer. Cancer 2009; 115: 3670-3679.

7 Kantoff PW, Higano CS, Shore ND, Berger ER, Small EJ, Penson DF et al. Sipuleucel-T immunotherapy for castration-resistant prostate cancer. $N$ Engl $J$ Med 2010; 363: 411-422.

8 de Bono JS, Logothetis CJ, Molina A, Fizazi K, North S, Chu L et al. Abiraterone and increased survival in metastatic prostate cancer. N Engl J Med 2011; 364 1995-2005.

9 Ryan CJ, Smith MR, de Bono JS, Molina A, Logothetis CJ, de Souza P et al. Abiraterone in metastatic prostate cancer without previous chemotherapy. N Engl J Med 2013; 368: 138-148.

10 Scher HI, Beer TM, Higano CS, Anand A, Taplin ME, Efastathiou E et al. Antitumour activity of MDV3100 in castration-resistant prostate cancer: a phase 1-2 study. Lancet 2010; 375: 1437-1446.

11 Scher HI, Fizazi K, Saad F, Taplin ME, Sterberg CN, Miller K et al. Increased survival with enzalutamide in prostate cancer after chemotherapy. N Engl J Med 2012; 367: 1187-1197.

12 Efstathiou E, Titus M, Tsavachidou D, Tzelepi V, Wen S, Hoang A et al. Effects of abiraterone acetate on androgen signaling in castrate-resistant prostate cancer in bone. J Clin Oncol 2012; 30: 637-643.

13 Tran C, Ouk S, Clegg NJ, Chen Y, Watson PA, Arora V et al. Development of a second-generation antiandrogen for treatment of advanced prostate cancer. Science 2009; 324: 787-790.

14 Fizazi K, Scher HI, Molina A, Logothetis CJ, Chi KN, Jones RJ et al. Abiraterone acetate for treatment of metastatic castration-resistant prostate cancer: final overall survival analysis of the COU-AA-301 randomised, double-blind, placebo-controlled phase 3 study. Lancet Oncol 2012; 13: 983-992.

15 Attard G, Cooper CS, de Bono JS. Steroid hormone receptors in prostate cancer: a hard habit to break? Cancer Cell 2009; 16: 458-462.

16 Scher HI, Sawyers CL. Biology of progressive, castration-resistant prostate cancer: directed therapies targeting the androgen-receptor signaling axis. J Clin Oncol 2005; 23: 8253-8261.

17 Mohler JL, Gregory CW, Ford 3rd OH, Kim D, Weaver CM, Petrusz P et al. The androgen axis in recurrent prostate cancer. Clin Cancer Res 2004; 10: 440-448.

18 Locke JA, Guns ES, Lubik AA, Adomat HH, Hendy SC, Wood CA et al. Androgen levels increase by intratumoral de novo steroidogenesis during progression of castration-resistant prostate cancer. Cancer Res 2008; 68: 6407-6415.

19 Montgomery RB, Mostaghel EA, Vessella R, Hess DL, Kalhorn RF, Higano CS et al. Maintenance of intratumoral androgens in metastatic prostate cancer: a mechanism for castration-resistant tumor growth. Cancer Res 2008; 68 : 4447-4454.

20 Stanbrough M, Bubley GJ, Ross K, Golub TR, Rubin MA, Penning TM et al. Increased expression of genes converting adrenal androgens to testosterone in androgen-independent prostate cancer. Cancer Res 2006; 66: 2815-2825.

21 Chang KH, Li R, Papari-Zareei M, Watumull L, Zhao YD, Auchus RJ et al. Dihydrotestosterone synthesis bypasses testosterone to drive castrationresistant prostate cancer. Proc Natl Acad Sci USA 2011; 108: 13728-13733.

22 Saloniemi T, Jokela $H$, Strauss $L$, Pakarinen $P$, Poutanen $M$. The diversity of sex steroid action: novel functions of hydroxysteroid (17beta) dehydrogenases as revealed by genetically modified mouse models. J Endocrinol 2012 212: $27-40$

23 Mitsiades N, Sung CC, Schultz N, Danila DC, He B, Eedunuri VK et al. Distinct patterns of dysregulated expression of enzymes involved in androgen synthesis and metabolism in metastatic prostate cancer tumors. Cancer Res 2012; 72: 6142-6152.

24 Efstathiou E, Titus M, Tsavachidou D, Tzelepi V, Ween S, Hoang A et al. Effects of abiraterone acetate on androgen signaling in castrate-resistant prostate cancer in bone. J Clin Oncol 2012; 30: 637-643.

25 Visakorpi T, Hyytinen E, Koivisto P, Tanner M, Keinanen R, Palmberg C et al. In vivo amplification of the androgen receptor gene and progression of human prostate cancer. Nat Genet 1995; 9: 401-406.

26 Sharma A, Yeow WS, Ertel A, Coleman I, Clegg N, Thangavel C et al. The retinoblastoma tumor suppressor controls androgen signaling and human prostate cancer progression. J Clin Invest 2010; 120: 4478-4492.

27 Cai C, He HH, Chen S, Coleman I, Wang H, Fang Z et al. Androgen receptor gene expression in prostate cancer is directly suppressed by the androgen receptor through recruitment of lysine-specific demethylase 1. Cancer Cell 2011; 20: 457-471. 
28 Edwards J, Krishna NS, Grigor KM, Bartlett JM. Androgen receptor gene amplification and protein expression in hormone refractory prostate cancer. Br J Cancer 2003; 89: 552-556.

29 Bubendorf L, Kononen J, Koivisto P, Schraml P, Moch H, Gasser TC et al. Survey of gene amplifications during prostate cancer progression by high-throughout fluorescence in situ hybridization on tissue microarrays. Cancer Res 1999; 59: 803-806.

30 Mao X, Yu Y, Boyd LK, Ren G, Lin D, Chaplin T et al. Distinct genomic alterations in prostate cancers in Chinese and Western populations suggest alternative pathways of prostate carcinogenesis. Cancer Res 2010; 70: 5207-5212.

31 Ruiz C, Lenkiewicz E, Evers L, Holley T, Robeson A, Kiefer J et al. Advancing a clinically relevant perspective of the clonal nature of cancer. Proc Natl Acad Sci USA 2011; 108: 12054-12059.

32 Chen CD, Welsbie DS, Tran C, Baek SH, Chen R, Vessella R et al. Molecular determinants of resistance to antiandrogen therapy. Nat Med 2004; 10: 33-39.

33 Sirotnak FM, She Y, Khokhar NZ, Hayes P, Gerald W, Scher HI. Microarray analysis of prostate cancer progression to reduced androgen dependence: studies in unique models contrasts early and late molecular events. Mol Carcinog 2004; 41: $150-163$.

34 Tilley WD, Wilson CM, Marcelli M, McPhaul MJ. Androgen receptor gene expression in human prostate carcinoma cell lines. Cancer Res 1990; 50: 5382-5386.

35 Thompson J, Hyytinen ER, Haapala K, Rantala I, Helin HJ, Janne OA et al. Androgen receptor mutations in high-grade prostate cancer before hormonal therapy. Lab Invest 2003; 83: 1709-1713.

36 Haapala K, Hyytinen ER, Roiha M, Laurila M, Rantala I, Helin HJ et al. Androgen receptor alterations in prostate cancer relapsed during a combined androgen blockade by orchiectomy and bicalutamide. Lab Invest 2001; 81: 1647-1651.

37 Taplin ME, Bubley GJ, Shuster TD, Frantz ME, Spooner AE, Ogata GK et al. Mutation of the androgen-receptor gene in metastatic androgen-independent prostate cancer. N Engl J Med 1995; 332: 1393-1398.

38 Taplin ME, Bubley GJ, Ko YJ, Small EJ, Upton M, Rajeshkumar B et al. Selection for androgen receptor mutations in prostate cancers treated with androgen antagonist. Cancer Res 1999; 59: 2511-2515.

39 Zhao XY, Malloy PJ, Krishnan AV, Swami S, Navone NM, Peehl DM et al. Glucocorticoids can promote androgen-independent growth of prostate cancer cells through a mutated androgen receptor. Nat Med 2000; 6: 703-706.

40 Culig Z, Hobisch A, Cronauer MV, Cato AC, Hittmair A, Radmayr C et al. Mutant androgen receptor detected in an advanced-stage prostatic carcinoma is activated by adrenal androgens and progesterone. Mol Endocrinol 1993; 7 : $1541-1550$

41 Steinkamp MP, O'Mahony OA, Brogley M, Rehman H, Lapensee EW, Dhanasekaran $\mathrm{S}$ et al. Treatment-dependent androgen receptor mutations in prostate cancer exploit multiple mechanisms to evade therapy. Cancer Res 2009; 69: 4434-4442.

42 Dehm SM, Regan KM, Schmidt LJ, Tindall DJ. Selective role of an NH2-terminal WxxLF motif for aberrant androgen receptor activation in androgen depletion independent prostate cancer cells. Cancer Res 2007; 67: 10067-10077.

43 Dehm SM, Tindall DJ. Alternatively spliced androgen receptor variants. Endocr Relat Cancer 2011; 18: R183-R196.

44 Li Y, Hwang TH, Oseth LA, Hauge A, Vessella RL, Schmechel SC et al. AR intragenic deletions linked to androgen receptor splice variant expression and activity in models of prostate cancer progression. Oncogene 2012; 31: 4759-4767.

$45 \mathrm{Hu}$ R, Isaacs WB, Luo J. A snapshot of the expression signature of androgen receptor splicing variants and their distinctive transcriptional activities. Prostate 2011; 71: 1656-1667

46 Sun S, Sprenger CC, Vessella RL, Haugk K, Soriano K, Mostaghel EA et al. Castration resistance in human prostate cancer is conferred by a frequently occurring androgen receptor splice variant. J Clin Invest 2010; 120: 2715-2730.

$47 \mathrm{Hu}$ R, Lu C, Mostaghel EA, Yegnasubramanian S, Gurel M, Tannahill C et al. Distinct transcriptional programs mediated by the ligand-dependent full-length androgen receptor and its splice variants in castration-resistant prostate cancer. Cancer Res 2012; 72: 3457-3462.

48 Li Y, Chan SC, Brand LJ, Hwang TH, Silverstein KA, Dehm SM. Androgen receptor splice variants mediate enzalutamide resistance in castration-resistant prostate cancer cell lines. Cancer Res 2012; 73: 483-489.

49 Sadar MD. Small molecule inhibitors targeting the "achilles' heel" of androgen receptor activity. Cancer Res 2011; 71: 1208-1213.

50 Guo Z, Dai B, Jiang T, Xu K, Xie Y, Kim O et al. Regulation of androgen receptor activity by tyrosine phosphorylation. Cancer Cell 2006; 10: 309-319.

51 Dai B, Chen H, Guo S, Yang X, Linn DE, Sun F et al. Compensatory upregulation of tyrosine kinase Etk/BMX in response to androgen deprivation promotes castration-resistant growth of prostate cancer cells. Cancer Res 2010; 70: 5587-5596.
52 Mahajan K, Challa S, Coppola D, Lawrence H, Luo Y, Gevariya H et al. Effect of Ack1 tyrosine kinase inhibitor on ligand-independent androgen receptor activity. Prostate 2010; 70: 1274-1285.

53 Wang Q, Li W, Zhang Y, Yuan X, Xu K, Yu J et al. Androgen receptor regulates a distinct transcription program in androgen-independent prostate cancer. Cell 2009; 138: 245-256.

54 Ueda T, Mawji NR, Bruchovsky N, Sadar MD. Ligand-independent activation of the androgen receptor by interleukin- 6 and the role of steroid receptor coactivator-1 in prostate cancer cells. J Biol Chem 2002; 277: 38087-38094.

55 Gregory CW, He B, Johnson RT, Ford OH, Mohler JL, French FS et al. A mechanism for androgen receptor-mediated prostate cancer recurrence after androgen deprivation therapy. Cancer Res 2001; 61: 4315-4319.

56 Agoulnik IU, Vaid A, Nakka M, Alvarado M, Bingman 3rd WE, Erdem $\mathrm{H}$ et al. Androgens modulate expression of transcription intermediary factor 2 , an androgen receptor coactivator whose expression level correlates with early biochemical recurrence in prostate cancer. Cancer Res 2006; 66: 10594-10602.

$57 \mathrm{Xu} \mathrm{J,} \mathrm{Wu} \mathrm{RC,} \mathrm{O'Malley} \mathrm{BW.} \mathrm{Normal} \mathrm{and} \mathrm{cancer-related} \mathrm{functions} \mathrm{of} \mathrm{the} \mathrm{p160}$ steroid receptor co-activator (SRC) family. Nature reviews. Cancer 2009; 9: 615-630.

58 Holzbeierlein J, Lal P, LaTulippe E, Smith A, Satagopan J, Zhang L et al. Gene expression analysis of human prostate carcinoma during hormonal therapy identifies androgen-responsive genes and mechanisms of therapy resistance. Am J Pathol 2004; 164: 217-227.

59 Yuan X, Balk SP. Mechanisms mediating androgen receptor reactivation after castration. Urol Oncol 2009; 27: 36-41.

60 Taylor BS, Schultz N, Hieronymus H, Gopalan A, Xiao Y, Carver BS et al. Integrative genomic profiling of human prostate cancer. Cancer Cell 2010; 18: 11-22.

61 Gurel B, Iwata T, Koh CM, Jenkins RB, Lan F, Van Dang C et al. Nuclear MYC protein overexpression is an early alteration in human prostate carcinogenesis. Mod Pathol 2008; 21: 1156-1167.

62 Thompson TC, Southgate J, Kitchener G, Land H. Multistage carcinogenesis induced by ras and myc oncogenes in a reconstituted organ. Cell 1989; 56: 917-930.

63 Zhang X, Lee C, Ng PY, Rubin M, Shabsigh A, Buttyan R. Prostatic neoplasia in transgenic mice with prostate-directed overexpression of the c-myc oncoprotein. Prostate 2000; 43: 278-285.

64 Iwata T, Schultz D, Hicks J, Hubbard GK, Mutton LN, Lotan TL et al. MYC overexpression induces prostatic intraepithelial neoplasia and loss of Nkx3.1 in mouse luminal epithelial cells. PLoS One 2010; 5: e9427.

65 Ellwood-Yen K, Graeber TG, Wongvipat J, Iruela-Arispe ML, Zhang J, Matusik R et al. Myc-driven murine prostate cancer shares molecular features with human prostate tumors. Cancer Cell 2003; 4: 223-238.

66 Yang G, Goltsov AA, Ren C, Kurosaka S, Edamura K, Logothetis R et al. Caveolin-1 upregulation contributes to $\mathrm{c}-\mathrm{Myc}$-induced high-grade prostatic intraepithelial neoplasia and prostate cancer. Mol Cancer Res 2012; 10: 218-229.

67 Nupponen NN, Kakkola L, Koivisto P, Visakorpi T. Genetic alterations in hormonerefractory recurrent prostate carcinomas. Am J Pathol 1998; 153: 141-148.

68 Visakorpi T, Kallioniemi AH, Syvanen AC, Hyytinen ER, Karhu R, Tammela T et al. Genetic changes in primary and recurrent prostate cancer by comparative genomic hybridization. Cancer Res 1995; 55: 342-347.

69 Bernard D, Pourtier-Manzanedo A, Gil J, Beach DH. Myc confers androgenindependent prostate cancer cell growth. J Clin Invest 2003; 112: 1724-1731.

70 Courtney KD, Corcoran RB, Engelman JA. The PI3K pathway as drug target in human cancer. J Clin Oncol 2010; 28: 1075-1083.

71 Wang S, Gao J, Lei Q, Rozengurt N, Pritchard C, Jiao J et al. Prostate-specific deletion of the murine Pten tumor suppressor gene leads to metastatic prostate cancer. Cancer Cell 2003; 4: 209-221.

72 Stiles B, Groszer M, Wang S, Jiao J, Wu H. PTENless means more. Dev Biol 2004; 273: $175-184$.

73 Gao H, Ouyang X, Banach-Petrosky WA, Shen MM, Abate-Shen C. Emergence of androgen independence at early stages of prostate cancer progression in Nkx3.1; Pten mice. Cancer Res 2006; 66: 7929-7933.

74 Jiao J, Wang S, Qiao R, Vivanco I, Watson PA, Sawyers CL et al. Murine cell lines derived from Pten null prostate cancer show the critical role of PTEN in hormone refractory prostate cancer development. Cancer Res 2007; 67: 6083-6091.

75 Chee KG, Longmate J, Quinn DI, Chatta G, Pinski J, Twardowski P et al. The AKT inhibitor perifosine in biochemically recurrent prostate cancer: a phase II California/Pittsburgh cancer consortium trial. Clin Genitourin Cancer 2007; 5: 433-437.

76 Kinkade CW, Castillo-Martin M, Puzio-Kuter A, Yan J, Foster TH, Gao H et al. Targeting AKT/mTOR and ERK MAPK signaling inhibits hormone-refractory prostate cancer in a preclinical mouse model. J Clin Invest 2008; 118: 3051-3064.

77 Zhang W, Zhu J, Efferson CL, Ware C, Tammam J, Angagaw M et al. Inhibition of tumor growth progression by antiandrogens and mTOR inhibitor in a Pten-deficient mouse model of prostate cancer. Cancer Res 2009; 69: 7466-7472. 
78 Carver BS, Chapinski C, Wongvipat J, Hieronymus H, Chen Y, Chandarlapaty S et al. Reciprocal feedback regulation of PI3K and androgen receptor signaling in PTEN-deficient prostate cancer. Cancer Cell 2011; 19: 575-586.

79 Mulholland DJ, Tran LM, Li Y, Cai H, Morim A, Wang S et al. Cell autonomous role of PTEN in regulating castration-resistant prostate cancer growth. Cancer Cell 2011; 19: 792-804.

80 Lin HK, Wang L, Hu YC, Altuwaijri S, Chang C. Phosphorylation-dependent ubiquitylation and degradation of androgen receptor by Akt require $\mathrm{Mdm} 2 \mathrm{E} 3$ ligase. $E M B O$ J 2002; 21: 4037-4048.

81 Wang Y, Mikhailova M, Bose S, Pan CX, deVere White RW, Ghosh PM. Regulation of androgen receptor transcriptional activity by rapamycin in prostate cancer cell proliferation and survival. Oncogene 2008; 27: 7106-7117.

82 Ha S, Ruoff R, Kahoud N, Franke TF, Logan SK. Androgen receptor levels are upregulated by Akt in prostate cancer. Endocr Relat Cancer 2011; 18: 245-255.

83 Mellinghoff IK, Vivanco I, Kwon A, Tran C, Wongvipat J, Sawyers CL. HER2/neu kinase-dependent modulation of androgen receptor function through effects on DNA binding and stability. Cancer Cell 2004; 6: 517-527.

84 Brognard J, Sierecki E, Gao T, Newton AC. PHLPP and a second isoform, PHLPP2, differentially attenuate the amplitude of Akt signaling by regulating distinct Akt isoforms. Mol Cell 2007; 25: 917-931.

85 Muranen T, Selfors LM, Worster DT, Iwanicki MP, Song L, Morales FC et al. Inhibition of $\mathrm{PI} 3 \mathrm{~K} / \mathrm{mTOR}$ leads to adaptive resistance in matrix-attached cancer cells. Cancer Cell 2012; 21: 227-239.

86 Nakabayashi M, Werner L, Courtney KD, Buckle G, Oh WK, Bubley GJ et al. Phase II trial of RAD001 and bicalutamide for castration-resistant prostate cancer. BJU Int 2012; 110: 1729-1735.

87 Bakin RE, Gioeli D, Bissonette EA, Weber MJ. Attenuation of Ras signaling restores androgen sensitivity to hormone-refractory C4-2 prostate cancer cells. Cancer Res 2003; 63: 1975-1980.

88 Suzuki A, Nakano T, Mak TW, Sasaki T. Portrait of PTEN: messages from mutant mice. Cancer Sci 2008; 99: 209-213.

89 Mulholland DJ, Kobayashi N, Ruscetti M, Zhi A, Tran LM, Huang J et al. Pten loss and RAS/MAPK activation cooperate to promote EMT and metastasis initiated from prostate cancer stem/progenitor cells. Cancer Res 2012; 72: 1878-1889.

90 Wakefield LM, Roberts AB. TGF-beta signaling: positive and negative effects on tumorigenesis. Curr Opin Genet Dev 2002; 12: 22-29.

91 Padua D, Massague J. Roles of TGFbeta in metastasis. Cell Res 2009; 19: 89-102.

92 Seoane J. Escaping from the TGFbeta anti-proliferative control. Carcinogenesis 2006; 27: 2148-2156.

93 Steiner MS, Zhou ZZ, Tonb DC, Barrack ER. Expression of transforming growth factor-beta 1 in prostate cancer. Endocrinology 1994; 135: 2240-2247.

94 Wikstrom P, Stattin P, Franck-Lissbrant I, Damber JE, Bergh A. Transforming growth factor beta1 is associated with angiogenesis, metastasis, and poor clinical outcome in prostate cancer. Prostate 1998; 37: 19-29.

95 Jones $\mathrm{E}, \mathrm{Pu} \mathrm{H}$, Kyprianou N. Targeting TGF-beta in prostate cancer: therapeutic possibilities during tumor progression. Expert Opin Ther Targets 2009; 13 227-234.

96 Karan D, Kelly DL, Rizzino A, Lin MF, Batra SK. Expression profile of differentiallyregulated genes during progression of androgen-independent growth in human prostate cancer cells. Carcinogenesis 2002; 23: 967-975.

97 Qi W, Gao S, Wang Z. Transcriptional regulation of the TGF-beta1 promoter by androgen receptor. Biochem J 2008; 416: 453-462.

98 Qi W, Gao S, Chu J, Zhou L, Wang Z. Negative androgen-response elements mediate androgen-dependent transcriptional inhibition of TGF-beta1 and CDK2 promoters in the prostate gland. J Androl 2012; 33: 27-36.

99 Van Themsche C, Mathieu I, Parent S, Asselin E. Transforming growth factorbeta3 increases the invasiveness of endometrial carcinoma cells through phosphatidylinositol 3-kinase-dependent up-regulation of X-linked inhibitor of apoptosis and protein kinase c-dependent induction of matrix metalloproteinase-9. J Biol Chem 2007; 282: 4794-4802.

100 Vinals F, Pouyssegur J. Transforming growth factor beta1 (TGF-beta1) promotes endothelial cell survival during in vitro angiogenesis via an autocrine mechanism implicating TGF-alpha signaling. Mol Cell Biol 2001; 21: 7218-7230.

101 Wilkes MC, Mitchell H, Penheiter SG, Dore JJ, Suzuki K, Edens M et al. Transforming growth factor-beta activation of phosphatidylinositol 3-kinase is independent of Smad2 and Smad3 and regulates fibroblast responses via p21-activated kinase-2. Cancer Res 2005; 65: 10431-10440.

102 Ding Z, Wu CJ, Chu GC, Xiao Y, Ho D, Zhang J et al. SMAD4-dependent barrier constrains prostate cancer growth and metastatic progression. Nature 2011; 470: 269-273.

103 Aitchison AA, Veerakumarasivam A, Vias M, Kumar R, Hamdy FC, Neal DE et al. Promoter methylation correlates with reduced Smad4 expression in advanced prostate cancer. Prostate 2008; 68: 661-674.
104 Lai SL, Chien AJ, Moon RT. Wnt/Fz signaling and the cytoskeleton: potential roles in tumorigenesis. Cell Res 2009; 19: 532-545.

105 MacDonald BT, Tamai K, He X. Wnt/beta-catenin signaling: components, mechanisms, and diseases. Dev Cell 2009; 17: 9-26.

106 de la Taille A, Rubin MA, Chen MW, Vacherot F, de Medina SG, Burchardt M et al. Beta-catenin-related anomalies in apoptosis-resistant and hormone-refractory prostate cancer cells. Clin Cancer Res 2003; 9: 1801-1807.

107 Takeichi M. Cadherin cell adhesion receptors as a morphogenetic regulator. Science 1991; 251: 1451-1455.

108 Heuberger J, Birchmeier W. Interplay of cadherin-mediated cell adhesion and canonical Wnt signaling. Cold Spring Harb Perspect Biol 2010; 2: a002915.

109 Kypta RM, Waxman J. Wnt/beta-catenin signalling in prostate cancer. Nat Rev Urol 2012; 8: 418-428.

110 Truica $\mathrm{Cl}$, Byers S, Gelmann EP. Beta-catenin affects androgen receptor transcriptional activity and ligand specificity. Cancer Res 2000; 60: 4709-4713.

111 Mulholland DJ, Cheng H, Reid K, Rennie PS, Nelson CC. The androgen receptor can promote beta-catenin nuclear translocation independently of adenomatous polyposis coli. J Biol Chem 2002; 277: 17933-17943.

112 Egawa S, Kadmon D, Miller GJ, Scardino PT, Thompson TC. Alterations in mRNA levels for growth-related genes after transplantation into castrated hosts in oncogene-induced clonal mouse prostate carcinoma. Mol Carcinogenesis 1992; 5: 52-61.

113 Mulholland DJ, Dedhar S, Coetzee GA, Nelson CC. Interaction of nuclear receptors with the Wnt/beta-catenin/Tcf signaling axis: Wnt you like to know? Endocr Rev 2005; 26: 898-915.

114 Mulholland DJ, Read JT, Rennie PS, Cox ME, Nelson CC. Functional localization and competition between the androgen receptor and T-cell factor for nuclear beta-catenin: a means for inhibition of the Tcf signaling axis. Oncogene 2003; 22 5602-5613.

115 Chesire DR, Isaacs WB. Ligand-dependent inhibition of beta-catenin/TCF signaling by androgen receptor. Oncogene 2002; 21: 8453-8469.

116 Wan X, Liu J, Lu JF, Tzelepi V, Yang J, Starbuck MW et al. Activation of betacatenin signaling in androgen receptor-negative prostate cancer cells. Clin Cancer Res 2012; 18: 726-736.

117 Yee D. The insulin-like growth factor system as a treatment target in breast cancer. Semin Oncol 2002; 29(3 Suppl 11): 86-95.

118 LeRoith D, Roberts Jr CT. The insulin-like growth factor system and cancer. Cancer Lett 2003; 195: 127-137.

119 Baserga R, Peruzzi F, Reiss K. The IGF-1 receptor in cancer biology. Int J Cancer 2003; 107: 873-877.

120 Burfeind $\mathrm{P}$, Chernicky $\mathrm{CL}$, Rininsland F, llan J. Antisense RNA to the type I insulin-like growth factor receptor suppresses tumor growth and prevents invasion by rat prostate cancer cells in vivo. Proc Natl Acad Sci USA 1996; 93: 7263-7268.

121 Heidegger I, Ofer P, Doppler W, Rotter V, Klocker H, Massoner P. Diverse functions of IGF/insulin signaling in malignant and noncancerous prostate cells: proliferation in cancer cells and differentiation in noncancerous cells. Endocrinology 2012; 153: 4633-4643.

122 Nickerson T, Chang F, Lorimer D, Smeekens SP, Sawyers CL, Pollak M. In vivo progression of LAPC-9 and LNCaP prostate cancer models to androgen independence is associated with increased expression of insulin-like growth factor I (IGF-I) and IGF-I receptor (IGF-IR). Cancer Res 2001; 61: 6276-6280.

123 Pandini G, Mineo R, Frasca F, Roberts Jr CT, Marcelli M, Vigneri R et al. Androgens up-regulate the insulin-like growth factor-I receptor in prostate cancer cells. Cancer Res 2005; 65: 1849-1857.

124 Vander Heiden MG, Cantley LC, Thompson CB. Understanding the Warburg effect: the metabolic requirements of cell proliferation. Science 2009; 324 1029-1033.

125 Zhao Y, Liu H, Liu Z, Ding Y, Ledoux SP, Wilson GL et al. Overcoming trastuzumab resistance in breast cancer by targeting dysregulated glucose metabolism Cancer Res 2011; 71: 4585-4597.

126 Nakano A, Miki H, Nakamura S, Harada T, Oda A, Amou H et al. Up-regulation of hexokinasell in myeloma cells: targeting myeloma cells with 3-bromopyruvate. J Bioenerg Biomembr 2012; 44: 31-38.

127 Moon JS, Jin WJ, Kwak JH, Kim HJ, Yun MJ, Kim JW et al. Androgen stimulates glycolysis for de novo lipid synthesis by increasing the activities of hexokinase 2 and 6-phosphofructo-2-kinase/fructose-2,6-bisphosphatase 2 in prostate cancer cells. Biochem J 2011; 433: 225-233.

128 Massie CE, Lynch A, Ramos-Montoya A, Boren J, Stark R, Fazli L et al. The androgen receptor fuels prostate cancer by regulating central metabolism and biosynthesis. EMBO J 2011; 30: 2719-2733.

129 Faubert B, Boily G, Izreig S, Griss T, Samborska B, Dong Z et al. AMPK is a negative regulator of the Warburg effect and suppresses tumor growth in vivo. Cell Metab 2013; 17: 113-124. 
130 Vaz CV, Alves MG, Marques R, Moreira PI, Oliveira PF, Maia CJ et al. Androgenresponsive and nonresponsive prostate cancer cells present a distinct glycolytic metabolism profile. Int J Biochem Cell Biol 2012; 44: 2077-2084.

131 Ros S, Santos CR, Moco S, Baenke F, Kelly G, Howell M et al. Functional metabolic screen identifies 6-phosphofructo-2-kinase/fructose-2,6-biphosphatase 4 as an important regulator of prostate cancer cell survival. Cancer Discov 2012; 2: 328-343.

132 Lin Y, Wang F. FGF signalling in prostate development, tissue homoeostasis and tumorigenesis. Biosci Rep 2010; 30: 285-291.

133 Ozen M, Giri D, Ropiquet F, Mansukhani A, Ittmann M. Role of fibroblast growth factor receptor signaling in prostate cancer cell survival. J Natl Cancer Inst 2001; 93: $1783-1790$

134 Memarzadeh S, Xin L, Mulholland DJ, Mansukhani A, Wu H, Teitell MA et al. Enhanced paracrine FGF10 expression promotes formation of multifocal prostate adenocarcinoma and an increase in epithelial androgen receptor. Cancer Cell 2007; 12: 572-585.

135 Acevedo VD, Gangula RD, Freeman KW, Li R, Zhang Y, Wang F et al. Inducible FGFR-1 activation leads to irreversible prostate adenocarcinoma and an epithelial-to-mesenchymal transition. Cancer Cell 2007; 12: 559-571.

136 Birchmeier C, Birchmeier W, Gherardi E, Vande Woude GF. Met, metastasis, motility and more. Nat Rev Mol Cell Biol 2003; 4: 915-925.

137 Varkaris A, Corn PG, Gaur S, Dayyani F, Logothetis CJ, Gallick GE. The role of HGF/ c-Met signaling in prostate cancer progression and c-Met inhibitors in clinical trials. Expert Opin Investig Drugs 2011; 20: 1677-1684.

138 Knudsen BS, Gmyrek GA, Inra J, Scherr DS, Vaughan ED, Nanus DM et al. High expression of the Met receptor in prostate cancer metastasis to bone. Urology 2002; 60: 1113-1117.

139 Verras M, Lee J, Xue H, Li TH, Wang Y, Sun Z. The androgen receptor negatively regulates the expression of c-Met: implications for a novel mechanism of prostate cancer progression. Cancer Res 2007; 67: 967-975.

140 Smith DC, Smith MR, Sweeney C, Elfiky AA, Logothetis C, Corn PG et al. Cabozantinib in patients with advanced prostate cancer: results of a phase II randomized discontinuation trial. J Clin Oncol 2013; 31: 412-419.

141 Sun $Y$, Wang BE, Leong KG, Yue P, Li L, Khunjhunwala $\mathrm{S}$ et al. Androgen deprivation causes epithelial-mesenchymal transition in the prostate: implications for androgen-deprivation therapy. Cancer Res 2012; 72: 527-536.

142 Zhu ML, Kyprianou N. Role of androgens and the androgen receptor in epithelial-mesenchymal transition and invasion of prostate cancer cells. FASEB J 2010; 24: 769-777.

143 Jeter CR, Liu B, Liu X, Chen X, Liu C, Calhoun-Davis T et al. NANOG promotes cancer stem cell characteristics and prostate cancer resistance to androgen deprivation. Oncogene 2011; 30: 3833-3845.

144 Sternberg PW, Schmid SL. Caveolin, cholesterol and Ras signalling. Nat Cell Biol 1999; 1: E35-E37.
145 Williams TM, Lisanti MP. Caveolin-1 in oncogenic transformation, cancer, and metastasis. Am J Physiol Cell Physiol 2005; 288: C494-C506.

146 Shatz M, Liscovitch M. Caveolin-1: a tumor-promoting role in human cancer. Int J Radiat Biol 2008; 84: 177-189.

147 Thompson TC, Tahir SA, Li L, Watanabe M, Naruishi K, Yang G et al. The role of caveolin-1 in prostate cancer: clinical implications. Prostate Cancer Prostatic Dis 2010; 13: 6-11.

148 Tahir SA, Ren C, Timme TL, Gdor Y, Hoogeveen R, Morrisett JD et al. Development of an immunoassay for serum caveolin-1: a novel biomarker for prostate cancer. Clin Cancer Res 2003; 9(10 Pt 1): 3653-3659.

149 Tahir SA, Frolov A, Hayes TG, Mims MP, Miles BJ, Lerner SP et al. Preoperative serum caveolin-1 as a prognostic marker for recurrence in a radical prostatectomy cohort. Clin Cancer Res 2006; 12: 4872-4875.

150 Yang G, Truong LD, Timme TL, Ren C, Wheeler TM, Park SH et al. Elevated expression of caveolin is associated with prostate and breast cancer. Clin Cancer Res 1998; 4: 1873-1880.

151 Li L, Yang G, Ebara S, Satoh T, Nasu Y, Timme TL et al. Caveolin-1 mediates testosterone-stimulated survival/clonal growth and promotes metastatic activities in prostate cancer cells. Cancer Res 2001; 61: 4386-4392.

152 Mouraviev V, Li L, Tahir SA, Yang G, Timme TM, Goltsov A et al. The role of caveolin1 in androgen insensitive prostate cancer. J Urol 2002; 168(4 Pt 1): 1589-1596.

153 Nasu Y, Timme TL, Yang G, Bangma CH, Li L, Ren C et al. Suppression of caveolin expression induces androgen sensitivity in metastatic androgen-insensitive mouse prostate cancer cells. Nat Med 1998; 4: 1062-1064.

154 Tahir SA, Yang G, Goltsov AA, Watanabe M, Tabata K, Addai J et al. Tumor cell-secreted caveolin-1 has proangiogenic activities in prostate cancer. Cancer Res 2008; 68: 731-739.

155 Li L, Ren CH, Tahir SA, Ren C, Thompson TC. Caveolin-1 maintains activated Akt in prostate cancer cells through scaffolding domain binding site interactions with and inhibition of serine/threonine protein phosphatases PP1 and PP2A. Mol Cell Biol 2003; 23: 9389-9404.

156 Li L, Ren C, Yang G, Goltsov AA, Tabata K, Thompson TC. Caveolin-1 promotes autoregulatory, Akt-mediated induction of cancer-promoting growth factors in prostate cancer cells. Mol Cancer Res 2009; 7: 1781-1791.

157 Tahir SA, Kurosaka S, Tanimoto R, Goltsov AA, Park S, Thompson TC. Serum caveolin-1, a biomarker of drug response and therapeutic target in prostate cancer models. Cancer Biol Ther 2012; 14: 117-126.

158 Tahir SA, Yang G, Goltsov AA, Song KD, Ren C, Wang J et al. Caveolin-1-LRP6 signaling module stimulates aerobic glycolysis in prostate cancer. Cancer Res 2013; 73: 1900-1911.

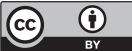

This work is licensed under a Creative Commons Attribution 3.0 Unported License. To view a copy of this license, visit http:// creativecommons.org/licenses/by/3.0/ 